\title{
Still Not Important Enough? COVID-19 Policy Views and Vote Choice
}

\author{
Eric Guntermann, University of California, Berkeley \\ Gabriel Lenz, University of California, Berkeley
}

\author{
Early Draft
}

September 25, 2020

\begin{abstract}
Scholars have long been skeptical of citizens' ability to vote on the basis of their policy views. Voters lack incentives to pay attention to politics and so are often unaware of the policy stances adopted by candidates and parties. However, some scholars have suggested that voter attention may increase when policy issues become important to them, such as when a crises disrupts their lives. The coronavirus pandemic provides a compelling test of this proposition. The COVID-19 pandemic is one of the most severe crises the United States has faced. Many voters also know people who have tested positive and in some cases died from the virus. It is thus salient and important to many if not most voters. Despite this context, we assess voters' knowledge about the candidates' positions on coronavirus issues and find low levels. In the absence of knowledge, voters project their own policy views onto their preferred candidate.
\end{abstract}


In canonical models of voting and representation, citizens vote for the candidate whose policy stances are closest to their own (Downs 1957). However, voters' policy attitudes have long been known to be inconsistent and unstable (Converse 1964). The attitudes they report on surveys often reflect the considerations that are at "the top of their head" (Zaller 1992). Voters also tend to adopt the positions of their preferred candidate (Brody and Page 1972; Lenz 2012). Moreover, voters frequently lack knowledge about candidates' positions on major issues in American politics (Freeder, Lenz and Turney 2019). Consequently, some scholars have long been skeptical that policy issues have much impact on the way people vote (Campbell et al. 1960). Instead, most voters simply vote for the candidate from the party they identify with (Bartels 2000).

In part, this may simply reflect rational ignorance on the part of voters (Downs 1957). Given the incredibly small likelihood of a voter casting a decisive vote, voters have little incentive to learn about politics. As Dahl $(1966,305)$ wrote, "politics is a sideshow in the great circus of life." The problem of how voters hold politicians accountable despite the collective action problem at the heart of democracy is sometimes called the "democratic dilemma."

However, scholars of voting behavior have long recognized that voters may be able to vote on the basis of policy attitudes that are salient, particularly if they are personally important to them (Converse 1964; Krosnick 1988). According to this perspective, voters are motivated to search for information on important issues and to think more deeply about them (Boninger et al. 1995). While there is evidence that voters seek out information about issues that are important to them (Bolsen and Leeper 2013), the evidence that importance increases issue voting is mixed at best (Bartle and Laycock 2012; Grynaviski and Corrigan 2006; Leeper and Robison 2020).

Given that the 2020 presidential election falls in the midst of one of the most severe crises in US history - the coronavirus pandemic - it provides the opportunity to study whether such severe crises motivate voters to learn about politics, especially to learn what they need to 
know to hold candidates accountable. In this paper, we examine whether we see this learning among all US residents - since the virus has affected everyone - but also among individuals who are more deeply affected by it.

One key limitation to the study of importance and issue voting is the measure of issue importance. Most scholars rely on subjective measures of personal or national importance (Boninger et al. 1995; Krosnick 1988). However, many voters' responses to these questions seem to reflect the salience of issues in campaigns and not necessarily their personal importance (Bartle and Laycock 2012; Johns 2010). One recent approach to measuring salience relies on analyzing decision-making by citizens (Hanretty, Lauderdale and Vivyan 2020). However, this approach can only distinguish importance by considering the outcome of interest, vote choice.

In this paper, we take a different approach. Since the virus affects all Americans, it should be personally important to virtually everyone. Fear of the virus, lockdowns, social distancing restrictions, school closures, office closures, and travel restrictions have disrupted lives in a way Americans have not experienced since at least the great wars. The virus has also affected some individuals even more deeply, including those who have caught the virus, have close friends or family members who have tested positive or who have even died. We assess whether these experiences increase the accuracy of voters' knowledge of parties' positions on the virus and whether they, in turn, increase the apparent weight of the virus on Americans' voting decisions in the November 2020 presidential election.

Prior studies have found that crises increase citizens' political engagement (Alaminos and Penalva 2012; Kern, Marien and Hooghe 2015). There is also evidence that voters responded to deaths in the Iraq War and to the 9/11 terrorist attacks (Gartner 2008). None of these studies, however, have measured the critical piece of knowledge voters need to hold politicians accountable: the candidates' policy stances. Does a major crisis induce citizens to learn what they need to know to vote for the candidate who best reflects their coronavirus policy views? 
We ran an online survey of 3,877 Americans between August 19th and 22nd on the online survey platform Lucid. We, first, consider Americans' preferences on coronavirus issues. We find that they are strongly supportive of measures to fight the virus. Even Trump supporters are broadly supportive of such policies. We then assess knowledge of the candidates' positions on these issues. Contrary to the importance argument, we find low levels of knowledge on virus-related issues, particularly among Trump voters. Moreover, levels of knowledge are lower among voters who have had the virus or who have a close friend or family member who has had it. Finally, we consider the weight of coronavirus attitudes on vote choice. We find that coronavirus attitudes are only associated with vote choice among high-knowledge voters. After controlling for partisanship and other policy views, they are not associated with vote choice among the voters who are most affected by the virus.

These findings cast doubt on the argument that voters tune in when issues deeply impact their daily lives. Even in the midst of a severe crisis, with an incumbent president out of line with voters, voter knowledge of this issue is not above levels we typically see for other issues.

\section{Issue Importance and Voting Behavior}

Ever since the classic works by Campbell et al. (1960) and Converse (1964), scholars have been aware of two major limitations to voters' ability to vote for the candidate who shares their policy preferences. First, policy preferences tend to be unstable (Converse 1964) and to reflect the considerations that become salient when respondents are asked about them (Zaller 1992). Second, voters lack knowledge of the positions adopted by competing candidates and parties (Campbell et al. 1960; Freeder, Lenz and Turney 2019).

Converse (1964) did suggest though that individual issues might have more importance to segments of the electorate he called "issue publics", for which they are particularly important. More recently, Krosnick (1988) has taken up this argument and argued that voters who 
subjectively believe an issue is important will put more effort into learning about the issue and thinking about it. In turn, they will be better able to connect their policy preferences to their vote choice (Boninger et al. 1995). People like to have consistent attitudes (Festinger 1957; Heider 1958) so they should put more effort into voting in a way that reflects their policy preferences on issues that are important to them. Self-interest may also play a role in fostering issue importance (Boninger et al. 1995; Miller, Krosnick and Fabrigar 2017).

While a compelling argument, the evidence that issue voting increases the weight of issues on voting behavior is limited (Krosnick 1988). There is evidence that issue importance leads people to pay more attention to information about an issue (Bolsen and Leeper 2013). There is also evidence that issue importance reduces elite influence on opinions (Lecheler, de Vreese and Slothuus 2009; Mullinix 2016). However, several studies in recent years find that issue importance has no effect on issue voting (Bartle and Laycock 2012; Grynaviski and Corrigan 2006; Leeper and Robison 2020).

Issue importance may have other effects on voters than stimulating issue voting. There are three ways voters can have consistent candidate and policy preferences (Brody and Page 1972; Krosnick 1990a). The most obvious is to change their vote choice to reflect their policy preferences (issue voting). However, they can also be persuaded by their preferred candidate to change their policy preferences and they can change their perception of the candidates' preferences by projecting their own position onto their preferred candidate and possibly projecting a less preferred position onto the other candidate (Conover and Feldman 1982; Martinez 1988).

The third possibility may be the easiest solution to achieve consistency between attitudes when an issue is relatively new and the candidates and parties do not have well-established reputations. Presumably, if an issue is important to them, voters will not adjust their policy views to reflect their candidate preferences. Moreover, adjusting their candidate preferences to reflect their policy preferences requires knowledge of the candidates' positions. Thus, projection may be easier. This is especially the case when a candidate adopts ambiguous 
stances on an issue (Brody and Page 1972; Martinez 1988). Previous research has shown that voters respond positively to candidate ambiguity by projecting their positions onto their preferred candidate (Tomz and Van Houweling 2009). Thus, on a new issue on which one or more candidates adopt ambiguous positions, projection is a likely strategy to reduce inconsistency between candidate and policy preferences.

\section{Our Data}

We ran an online pre-electoral survey using the opt-in online survey provider Lucid with 3,877 voting-age American respondents between August 19th and 22nd 2020. For a detailed study of Lucid, see Coppock and McClellan (2019). We created survey weights using iterative proportional fitting (raking) by matching the survey distributions on age, gender, race, Hispanic identity, and education to Census Bureau benchmarks. Given the growing problem with inattentiveness on opt-in panels (Aronow et al. 2020), we did not accept responses from individuals who cannot correctly report the date of the month.

We asked respondents to provide their positions on 35 policy issues. We also asked them to provide their perceptions of the candidates' positions on 14 of those issues. Table 1 shows the 14 issues for which we have both respondents' positions and their perceptions of the candidates' positions. We asked respondents whether they agree, disagree or neither agree nor disagree with each statement. Three of the issues relate to the coronavirus (Masks in Public, WHO, and Close Businesses). 
Table 1: Main Policy Issue Questions

\begin{tabular}{|l|l|}
\hline Improve Position of Blacks & The government should make every effort to improve the social and economic position of Blacks \\
\hline Gay Marriage Ban & A constitutional amendment banning same sex marriages \\
\hline Lower Taxes & Lowering federal taxes \\
\hline Abortion & Restrictions on whether a woman can get an abortion \\
\hline Background Checks for Guns & $\begin{array}{l}\text { Strengthening background checks to prevent guns from being sold to people with } \\
\text { criminal records or mental illness }\end{array}$ \\
\hline CO2 & Restricting the amount of carbon dioxide (CO2) factories can emit \\
\hline Muslim Ban & Preventing any Muslim who is not a US citizen from entering the country \\
\hline Repeal ACA & Repeal Affordable Care Act (ACA) \\
\hline WHO & The United States should be part of the World Health Organization (WHO) \\
\hline Mexico Wall & Building a wall along the Mexican border \\
\hline Masks in Public & Requiring people to wear masks in public to slow the spread of the coronavirus \\
\hline Free Trade & Increasing free trade with other countries \\
\hline Income Gap & Reducing the size of the income gap between rich and poor Americans \\
\hline Close Businesses & Closing non-essential businesses to slow the spread of the coronavirus \\
\hline
\end{tabular}

Note: These are the issues for which we have both respondents' own positions as well as their perceptions of the candidates' positions. Respondents were asked whether they and the candidates agree, disagree or neither agree nor disagree with each item.

In addition to these 14 issues, we asked respondents to place themselves on the same agreedisagree scale on 10 other issues. We further asked them how much effort they want from government on six other issues. Three of these issues are related to the virus: coronavirus testing, making sure people with the virus stay at home, and protecting Americans from the coronavirus. Finally, we asked respondents how much they want the government to spend on five more issues that are unrelated to the coronavirus.

For analyses of issue voting, following Ansolabehere, Rodden and Snyder (2008), we create seven policy scales with four to six items in each scale. These scales assess attitudes towards Blacks, redistribution, abortion, the environment, immigration, health care, and the coronavirus. The coronavirus scale has the most items (six) of any scale. All scales go from 0 to 1 where 1 is the most pro-Trump attitude. Scale reliability is mostly high. Cronbach's alpha is 0.80 for the attitudes towards Blacks scale, 0.77 for redistribution 0.80 for abortion, 0.61 for the environment, 0.78 for immigration, 0.60 for health care, and 0.84 for the coronavirus scale.

We also have items that do not fit into any of the scales. These are responses to questions about a constitutional amendment banning same-sex marriage, lowering federal taxes, strengthening background checks for gun sales, and increasing free trade with other countries. 
Like the scales, these items range from 0 to 1 where 1 is the most pro-Trump option.

We have two indicators that the coronavirus is particularly important to some voters. The first is a question asking respondents whether they, a close friend or a family member has tested positive for COVID-19 this year. Twenty-seven percent responded yes to this question. The second asks whether a close friend or family member has died from COVID19. Fifteen percent responded yes to this question. Though uncertainty exists about actual infection rates and death rates, these percentages are broadly in line with estimates from covid tracking models. ${ }^{1}$

\section{Results}

\subsection{Public Support for Coronavirus Policies}

What do Americans think about policies to protect them from the coronavirus? Coronavirus questions were asked in two formats. We asked respondents whether they agree, disagree or neither agree nor disagree with mask requirements in public, closing businesses to slow the spread of the virus, and about WHO membership. We also asked respondents how much effort they want the federal government to put into coronavirus testing, protecting Americans against the virus, and making sure people with the virus stay at home. The options are much more than now, somewhat more than now, the same as now, somewhat less than now, and much less than now.

Figure 1(a) shows the percentages of all respondents who agree with a mask requirement, closing non-essential businesses, and WHO membership. Figure 1(b) shows how much effort voters want from government to test for the coronavirus, protect Americans from the virus

\footnotetext{
${ }^{1}$ E.g., https://covid19-projections.com/us. For example, given death estimates by mid August, 2020, we would find about $15 \%$ of people knowing someone who died if the typical person knew 300 individuals. Estimates of people's average network size range widely but are typically in the 300-700 range, e.g., Gelman (2013).
} 
and to force Americans with the virus to stay at home.

Overall, Americans are supportive of policies to fight the virus. Sixty-nine percent agree with requiring masks in public (11 percent disagree), 48 percent agree with closing nonessential businesses (22 percent disagree), and 51 percent agree with WHO membership (20 percent disagree). Moreover, 70 percent want the government to do more to protect Americans from the virus (8 percent want it to do less), 70 percent want the government to do more to force infected people to stay at home (7 percent want the government to do less), and 65 percent want the government to do more to test people for the virus (10 percent want it to do less). Figure 1(c) and (d) show responses among Trump voters. With the exception of closing non-essential businesses and WHO membership, majorities of Trump voters support these policies to fight the coronavirus.

\subsection{Placement Knowledge}

We saw in the last section that Americans are strongly supportive of policies to fight the coronavirus. For voters to hold politicians accountable to these views, voters must have some sense of the candidates' stances (Campbell et al. 1960). How much knowledge do voters have of the candidates' stances on coronavirus policies? How do these compare to knowledge of stances on other policies? As explained above, we asked respondents their perceptions of the candidates' positions on 14 of the policy issues in addition to their own attitudes. These include three coronavirus issues: requiring masks in public, closing non-essential businesses, and WHO membership.

We consider respondents as knowing the candidates' stances if they placed Biden as more supportive of masks, closing non-essential businesses, and WHO membership than Trump. Recall that these questions had three response categories: "agree," "disagree," and "neither agree nor disagree." To get a question right, respondents had to place Biden at "agree" and Trump at either "neither agree nor disagree" or "disagree", on the one hand, or Biden at "neither agree nor disagree" and Trump at "disagree," on the other hand. To encourage 
(a) Responses to Coronavirus Policy

Questions Among All Respondents

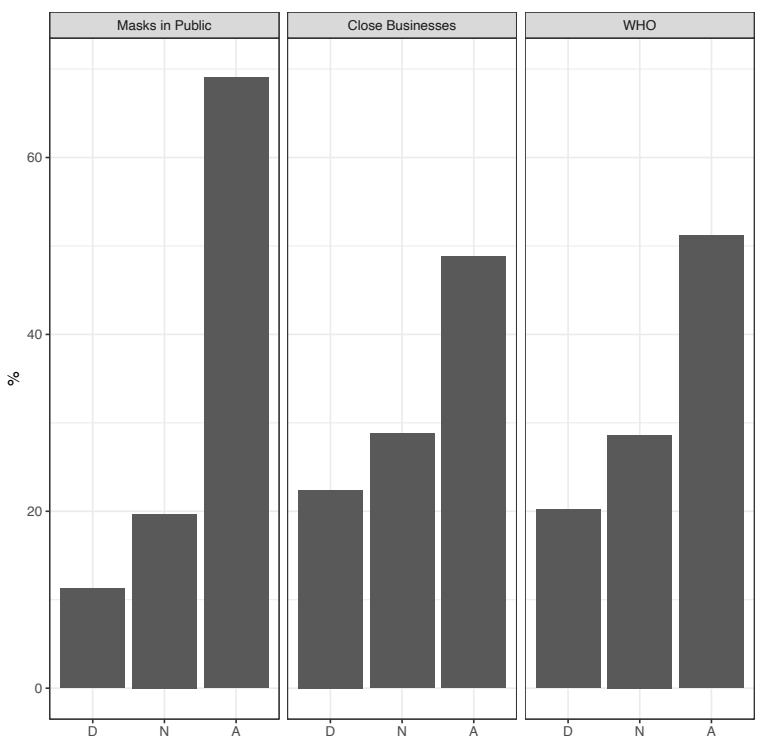

(c) Responses to Coronavirus Policy Questions Among Trump Voters

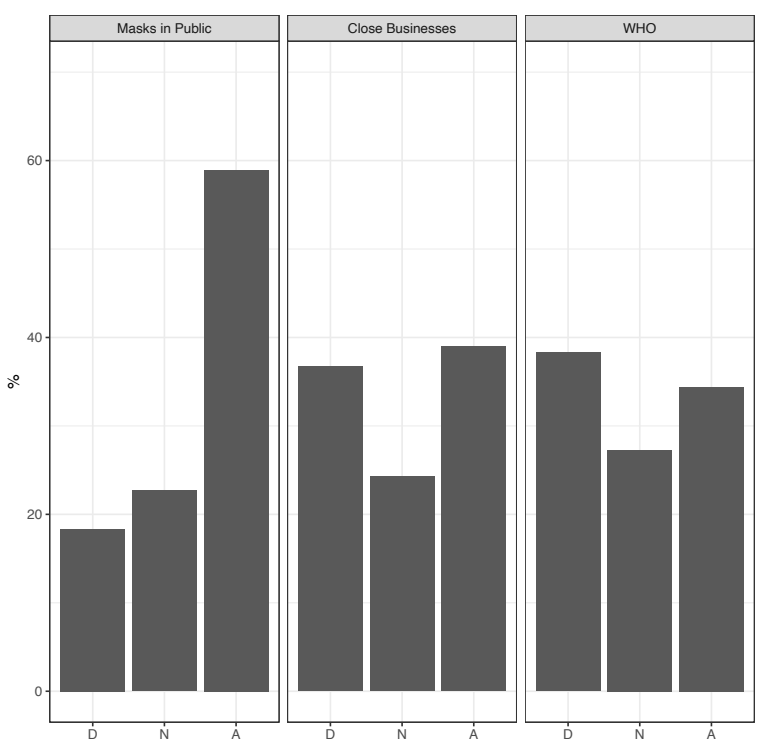

(b) Responses to Coronavirus Effort Questions Among All Respondents

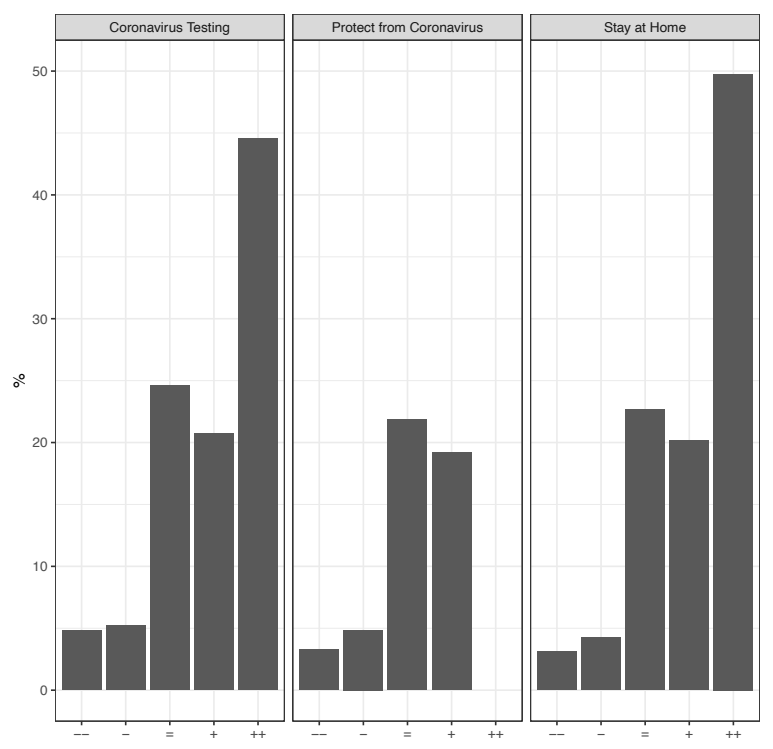

(d) Responses to Coronavirus Effort Questions Among Trump Voters

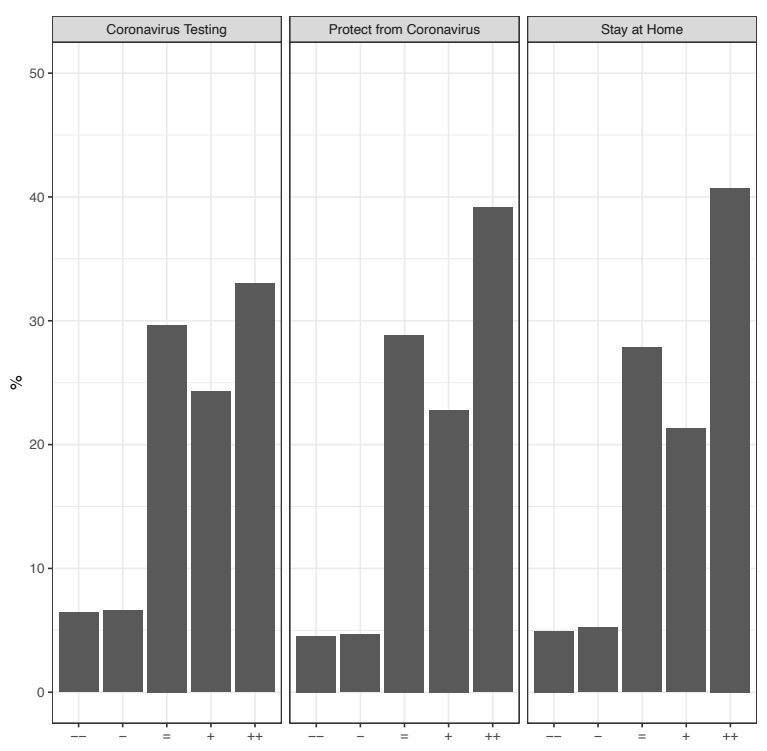

Figure 1: This figure shows that the public strongly supports aggressive measures to fight the virus, even among Trump supporters. In the left figures, A: agree, N: neither agree nor disagree, D: disagree. In the right figure, the percentages of Trump voters who give each response to each question about how much effort the federal government should put into each policy area. ++ : much more than now, + : somewhat more than now, $=$ : the same as now, -: somewhat less than now, -: much less than now. 
people to volunteer knowledge, we did not include a "don't know" option. We code the very small percentage of respondents who skipped these questions as incorrect (0-2 percent across all 14 policy items).

According to this measure, only thirty-nine percent of respondents correctly placed the candidates on the mask issue, only 41 percent did so on closing non-essential businesses, and only 47 percent correctly placed the candidates on the WHO. Given the enormity of the crisis, these levels of knowledge seem low. ${ }^{2}$

To put these in context, Figure 2 shows the percentage who place Trump on the conservative side of Biden on all 14 policy questions we asked about. These questions use the same response format as the coronavirus agree-disagree policy questions and we code correct responses in the same way. This figure reveals a limitation to Americans' policy voting behavior. Even on long-standing issues in American politics, like abortion, only about 40$50 \%$ of the public correctly answers these question. Given that $19 \%$ would get this right by chance alone, this is a low number. ${ }^{3}$ The two issues on which respondents' perception seem most accurate are building a wall on the Mexican border and repealing the ACA, both of which are highly salient issues that Republican and Democratic elites have emphasized over

\footnotetext{
${ }^{2}$ The pattern of incorrect responses seems consistent with low levels of knowledge. On the mask question, about half of respondents we classify as incorrect say both Trump and Biden agree that masks should be required in public. The next most common mistake, made by almost a quarter of incorrect respondents, is to say both candidates neither agree nor disagree. The third most common mistake is to say Trump agrees more than Biden, made by 10 percent of respondents. We classify only $3 \%$ as incorrect because they skipped the Biden or Trump placement questions.

${ }^{3}$ Respondents can respond "agree," "disagree," or "neither agree or disagree," or skip the placement question for each candidate, yielding $4 \times 4=16$ possible responses. They could place Biden as more supportive of masks in three ways, yielding a chance correct rate of $3 \div 16=0.1875$
} 
the last few years. These low levels of knowledge about presidential candidate positions are consistent with long-standing research findings (Layman and Carsey 2002; Freeder, Lenz and Turney 2019). ${ }^{4}$ Given the severity of the coronavirus, we might expect voter knowledge to be substantially higher on pandemic questions than on other questions. Instead, however, voter knowledge on pandemic questions seems typical of other policy items. The three pandemic questions fall in the middle of the distribution, below the items about the wall and the ACA but above a handful of issues that voters find tricky, such as free trade and lowering taxes.

It is important to note that these low levels of knowledge do not arise primarily because candidates took highly ambiguous positions on these issues, which even highly knowledgeable respondents would get wrong. Among respondents who are generally knowledgeable about policies - measured by their percent correct on other policy questions - the percent correct across all 14 policies, including the coronavirus policies, is typically above $90 \%$.

These low levels of policy knowledge are also not about attention, though attention may contribute. As we noted above, we screened out respondents who could not provide the date of the month. We also included a very difficult attention check with an obvious but wrong answer, which only $36 \%$ of respondents passed. Among these $36 \%$ we do see somewhat higher levels of knowledge but they are still low. The percent placing Biden as more supportive than Trump of masks in public rises from $39 \%$ in the full sample to only $46 \%$ in the group that passed this challenging attention check. Across all 14 issues, those passing this attention check place Trump as more conservative than Biden just 50\% of the time on average.

It is also important to note that even in groups with a candidate who reflects their attitudes, such as on the mask issue among Biden voters, we still do not see high levels of

\footnotetext{
${ }^{4}$ Appendix Figure A.3 presents the percent correct for all similar questions in ANES presidential election years, 1972-2016. The percentages in the Lucid survey are broadly consistent with the percentages in that figure, though somewhat lower when compared with recent ANES surveys, especially 2016. We discuss possible solutions for the difference in the appendix below the figure.
} 
knowledge. Figure 3 shows the percent correct across all 14 policies separately for Trump voters, Biden voters, and individuals who are unsure of their vote intentions, plan to vote for another candidate, or who do not plan to vote. It shows that even Biden supporters, who strongly support wearing masks and have a candidate who strongly supports wearing masks, still only correctly place the candidates about $60 \%$ of the time. 
Figure 2: Knowledge of Trump's and Biden's Stances Among All Respondents

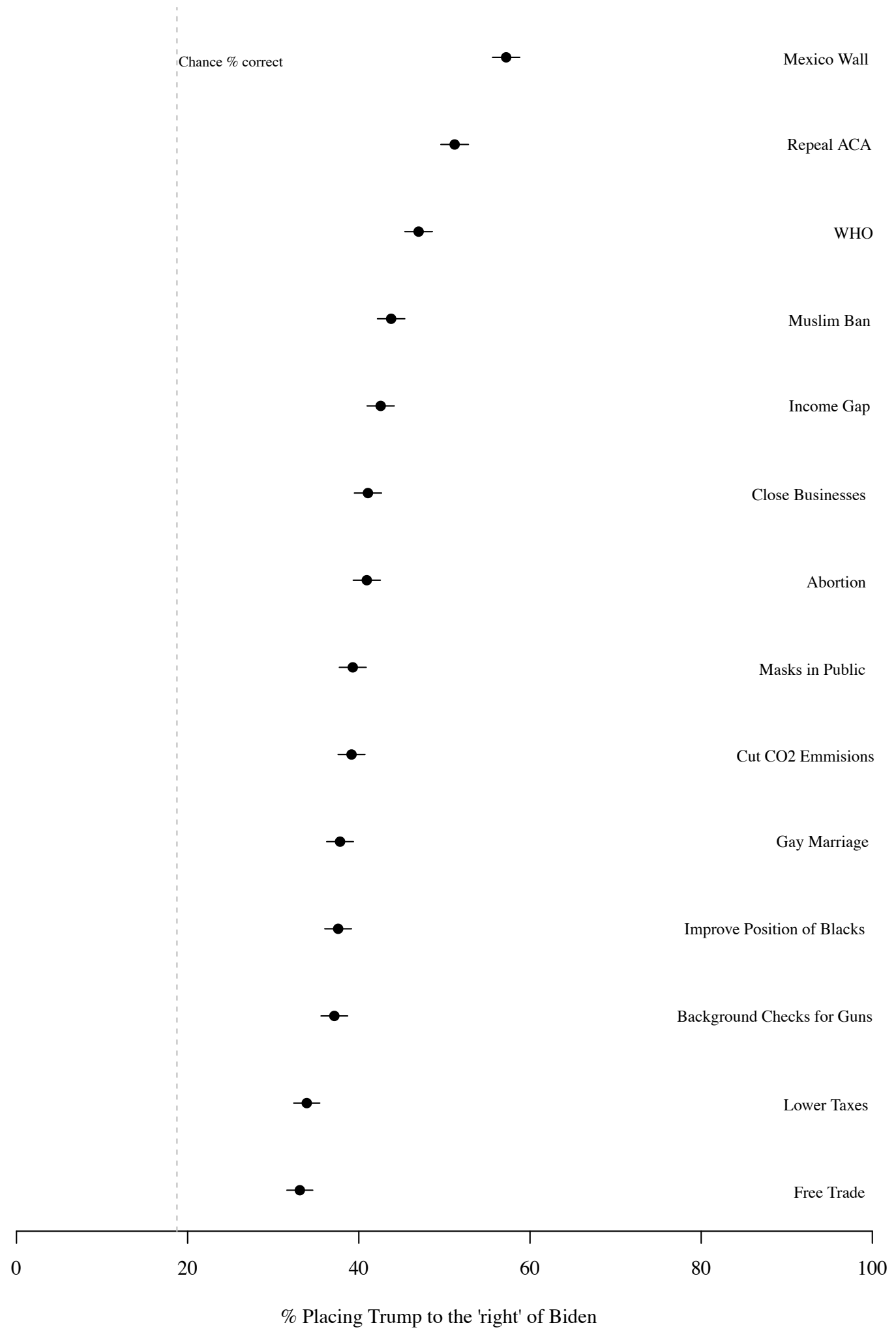

Note: This figure shows the percent placing Trump on the conservative side of Biden. It shows that, despite a once-in-a-century crisis, the public hasn't learned more about presidential candidate stances on crisis policies than typical for other issues. 
Figure 3: Knowledge of Trump's and Biden's Stances by Vote Choice

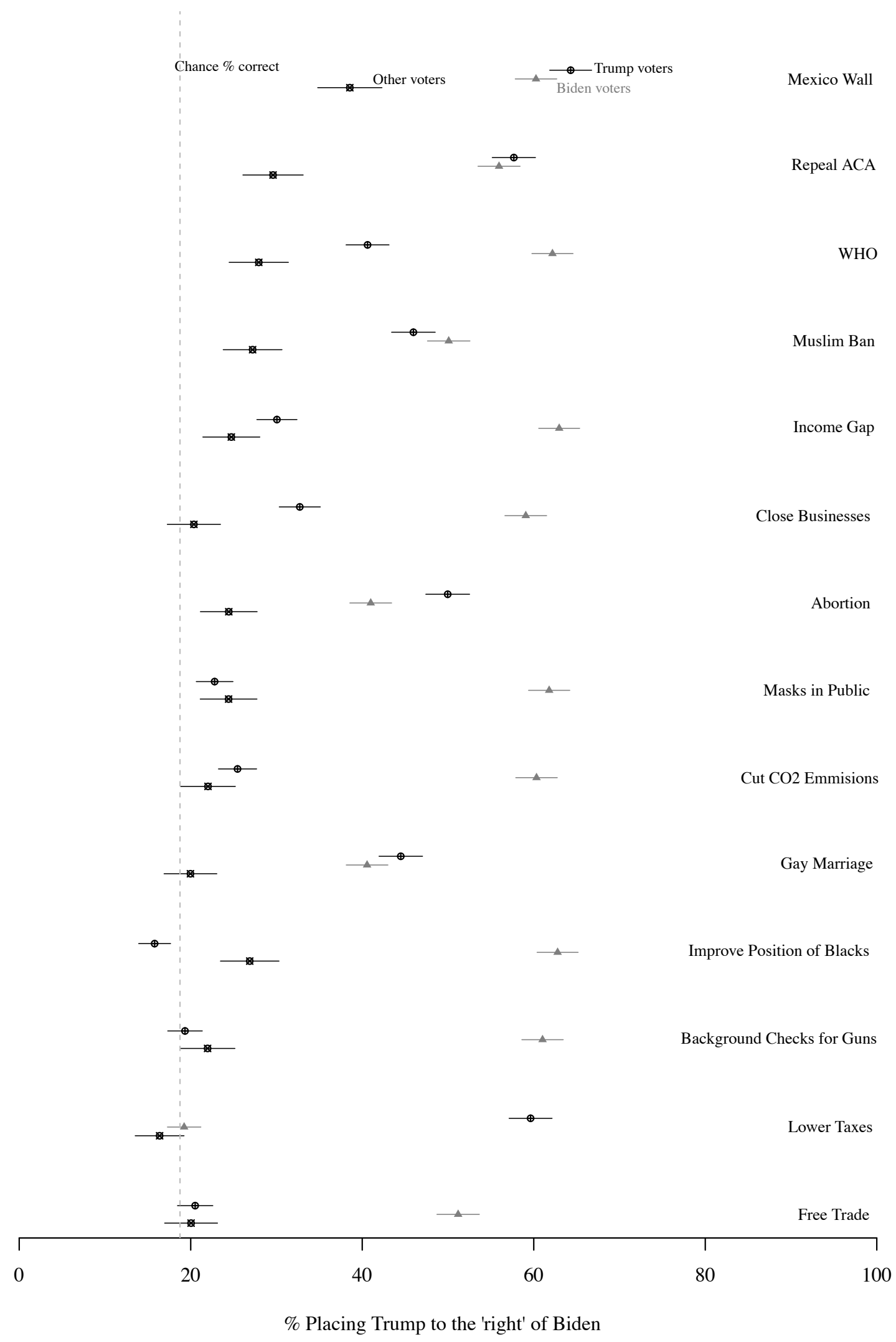

Note: This figure shows the percent placing Trump on the conservative side of Biden. It shows that, despite a once-in-a-century crisis, knowledge about candidate positions on that crisis are not above the low levels we typically see for most issues. 
Nevertheless, the task may be unusually hard for Trump voters. They are supportive of aggressive measures on the virus and, therefore, out of line with Trump. Trump has also sent conflicting signals about masks and other coronavirus policies. ${ }^{5}$ How much has that reduced accuracy among Trump supporters?

Figure 4 shows perceptions of each candidates' stances by the candidates' own voters. Among Trump voters, we see signs that his lack of alignment with them is lowering knowledge. A majority (56 percent) perceived that Trump supports masks and large minorities perceived that he supports closing non-essential businesses (35 percent) and the WHO (31 percent). The figure also shows that large majorities of Biden voters perceived him as supporting closing non-essential businesses, a mask requirement and WHO membership. As we can see, few people skipped the questions asking about the candidates' coronavirus stances. See the Appendix for voters' perceptions of the candidates on all the issues.

\begin{tabular}{cccccc}
\hline${ }^{5}$ For example, he once called masks patriotic & (see \\
https://www.nytimes.com/2020/07/21/us/politics/trump-coronavirus-masks.html).
\end{tabular}


(a) Perceptions of Biden's Stances by his Voters

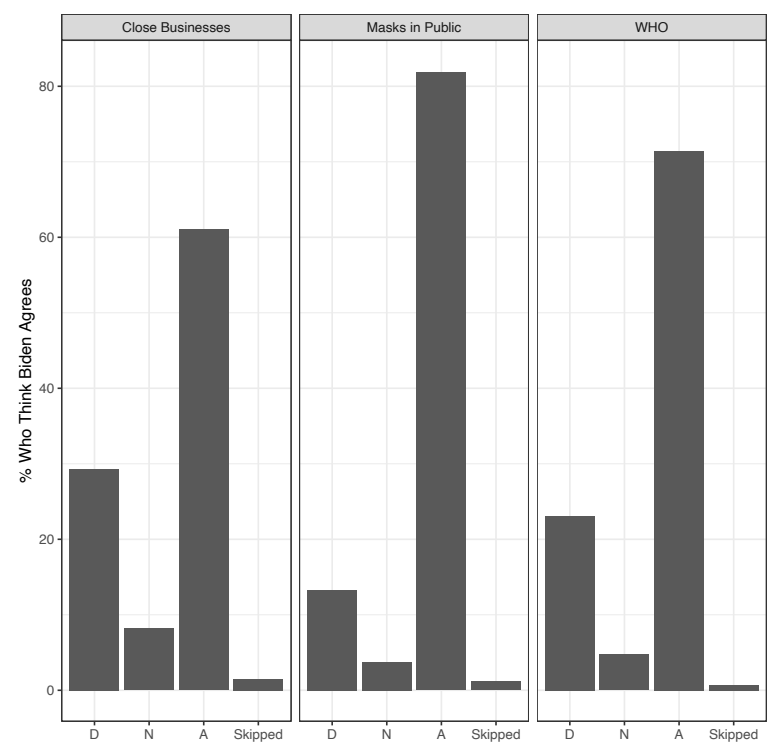

(b) Perceptions of Trump's Stances by his Voters

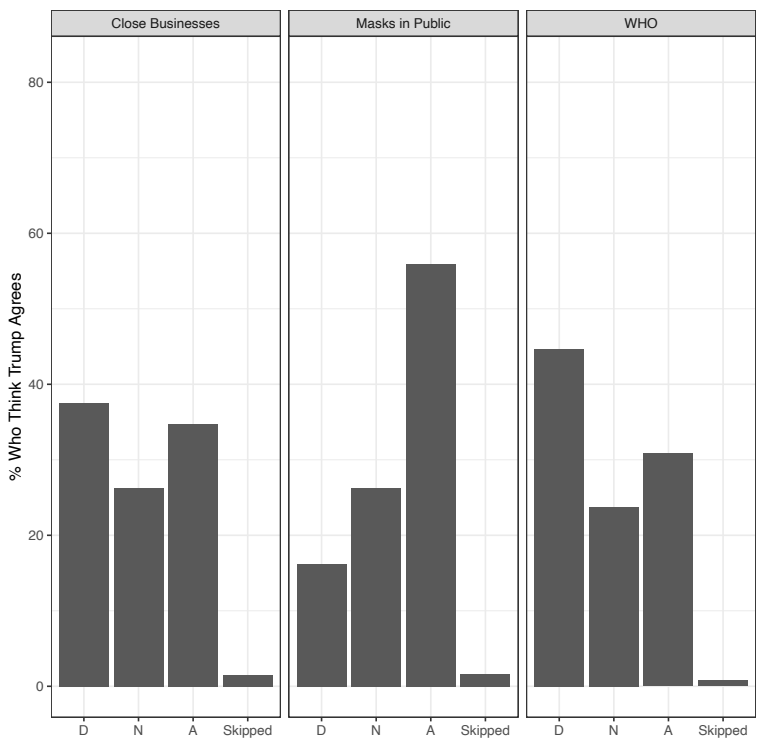

Figure 4: Perceptions of Candidate Stances by their Voters

Note: Bars in these figure show the percentages of each candidate's voters with each opinion on each of the coronavirus issues who perceive their candidate as agreeing with the policy.

Trump voters' perceptions of Trump in Figure 4 seem consistent with projection, and Biden voters' perceptions of Biden could be as well. Figure 5 provides more direct evidence. It shows the percentage of each candidate's voters who "agree," "neither agree nor disagree," or "disagree" with each policy who believe their preferred candidate agrees with the policy. Overwhelming majorities of voters who agree with each policy also think their preferred candidate agrees with it as well. Very few voters who disagree with policies believe their preferred candidate agrees with them. Thus, voters appear to be projecting their attitudes onto their preferred candidate. 
(a) Perceptions that Biden Agrees with Each Policy by Biden Voters' Own Preference

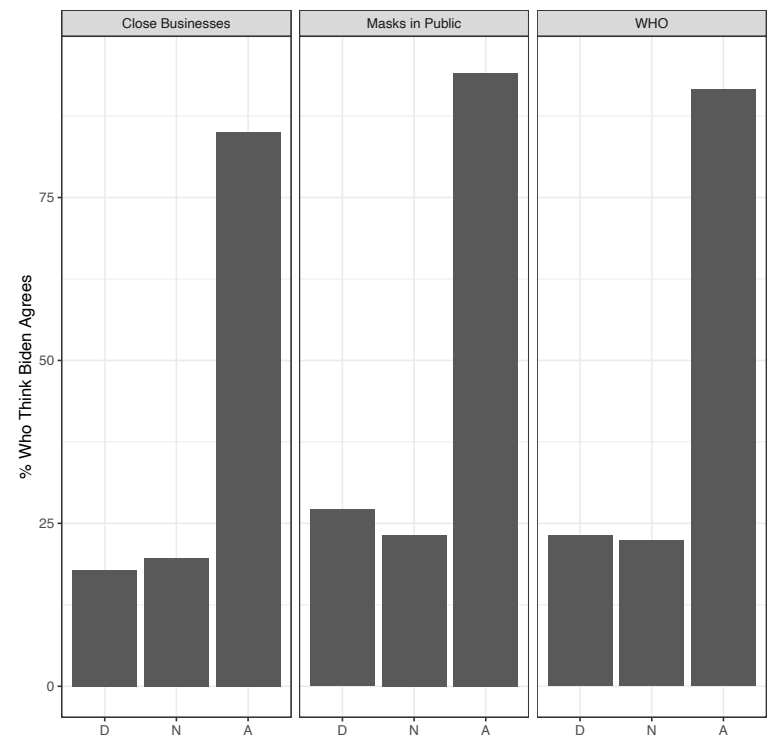

(b) Perceptions that Trump Agrees with Each Policy by Trump Voters' Own Preference

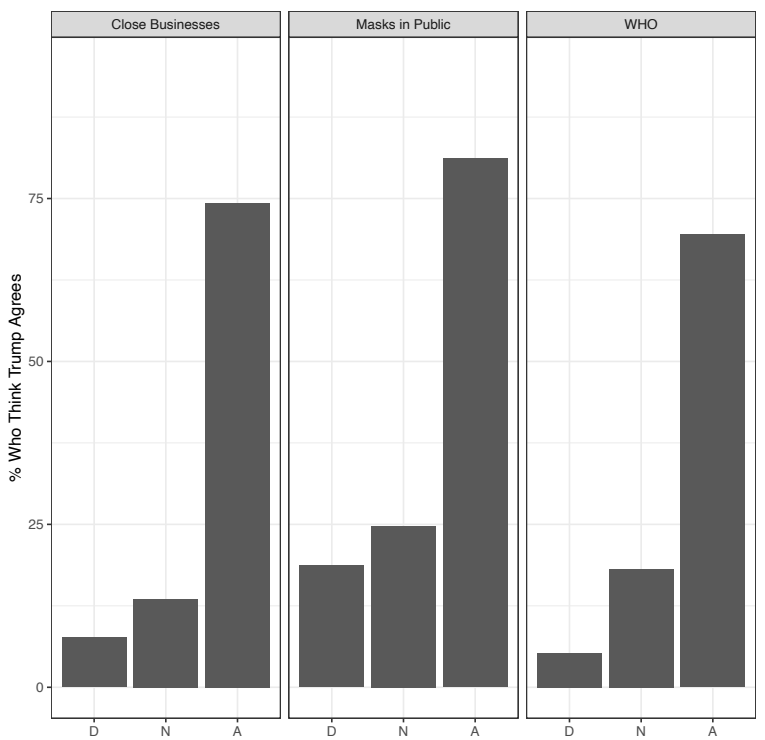

Figure 5: Perceptions of Candidate Stances by their Voters' Own Preference

Note: Bars in these figure show the percentages of each candidate's voters with each opinion on each of the coronavirus issues who perceive their candidate as agreeing with the policy.

It is possible that voters project only in the absence of knowledge, but it's also possible that voters deceive themselves through motivated reasoning (Kunda 1990) or deceive the researcher through cheerleading (Bullock et al. 2015). To gain a sense for the latter two mechanisms, we examine perceptions among voters with high knowledge of candidates' stances in general. We create a general knowledge measure based on the 11 candidate position questions not about the virus. We gave respondents one point for each issue on which they placed Trump on the conservative side of Biden. Among the top $20 \%$ of respondents on this measure, those voting for Biden saw Biden as more pro-mask than Trump 96\% of the time. In contrast, those voting for Trump did so only $63 \%$ of the time. People who did not support either candidate but had high knowledge did so $86 \%$ of the time. These findings are consistent with knowledgeable Trump voters engaging in motivated reasoning or cheerleading - projecting their own position onto their preferred candidate to avoid being inconsistent. Clearly, lack of knowledge is not the only problem. 
Do voters for whom the coronavirus is particularly important have better knowledge of the candidates' stances? We consider the two measures of issue importance: whether the respondent has a close friend or family member who tested positive for COVID-19 and whether they have a close friend or family member who died from COVID-19. On all three virus policies and using either measure of importance, we find that importance actually decreases the percentage of respondents who place the candidates on the correct sides of each other. For example, 40 percent of respondents without a close friend or family member who died correctly place the candidates on the mask issue, but only 34 percent of those who lost a close friend correctly place the candidates on that issue.

In, sum, we find that voter knowledge of Trump and Biden stances on coronavirus policy is surprisingly low. The pandemic has disrupted voters' lives and yet they have not learned more about this issue than other issues. To some extent, voters' tendency to engage in motivated reasoning and cheerleading may lower the level of knowledge among Trump voters.

\subsection{Voting on an Important Issue}

The previous section showed that voters lack a key pre-condition for voting on the basis of a policy issue: they lack knowledge of the candidates' positions on the coronavirus, despite its importance. Does this prevent them from voting in a way that reflects their preferences on this issue?

We examine this question by estimating models of vote choice. Because the data are cross-sectional, we cannot assume independent variables are exogenous. These estimates can, therefore, only be suggestive. Figure 6 shows regression coefficients from a linear probability model of binary Trump (vs Biden) vote choice on each of the policy scales mentioned above as well as the individual policy items that do not fit into one of the scales. Models also control for demographics and for the standard seven-point party identification scale. For this analysis, policy items are coded so higher values represent the positions most favorable to Trump. In the case of the coronavirus, for example, higher values indicate that a voter is 
less supportive of measures to fight the virus. All the variables are rescaled to vary between zero and one. The figure indicates the number of items in each scale next to the name of each policy area.

The figure shows that the six-item coronavirus attitude index is related to vote choice. Coronavirus attitudes are the third most strongly related to vote choice, after immigration and health care attitudes. Despite the extremity of the coronavirus crisis, respondents who who most strongly oppose policies to fight the coronavirus are only 11 percentage points more supportive of Trump than those who strongly support them. Nevertheless, we should be cautious though because these results come from a single cross-section and could, therefore, reflect persuasion, whereby voters adopt the policy positions of their preferred candidate (Brody and Page 1972; Lenz 2012). This finding may, therefore, overestimate the impact of coronavirus attitudes on vote choice. 
Figure 6: Marginal Effect of Policy Attitudes in Each Issue Area on Intention to Vote for Trump

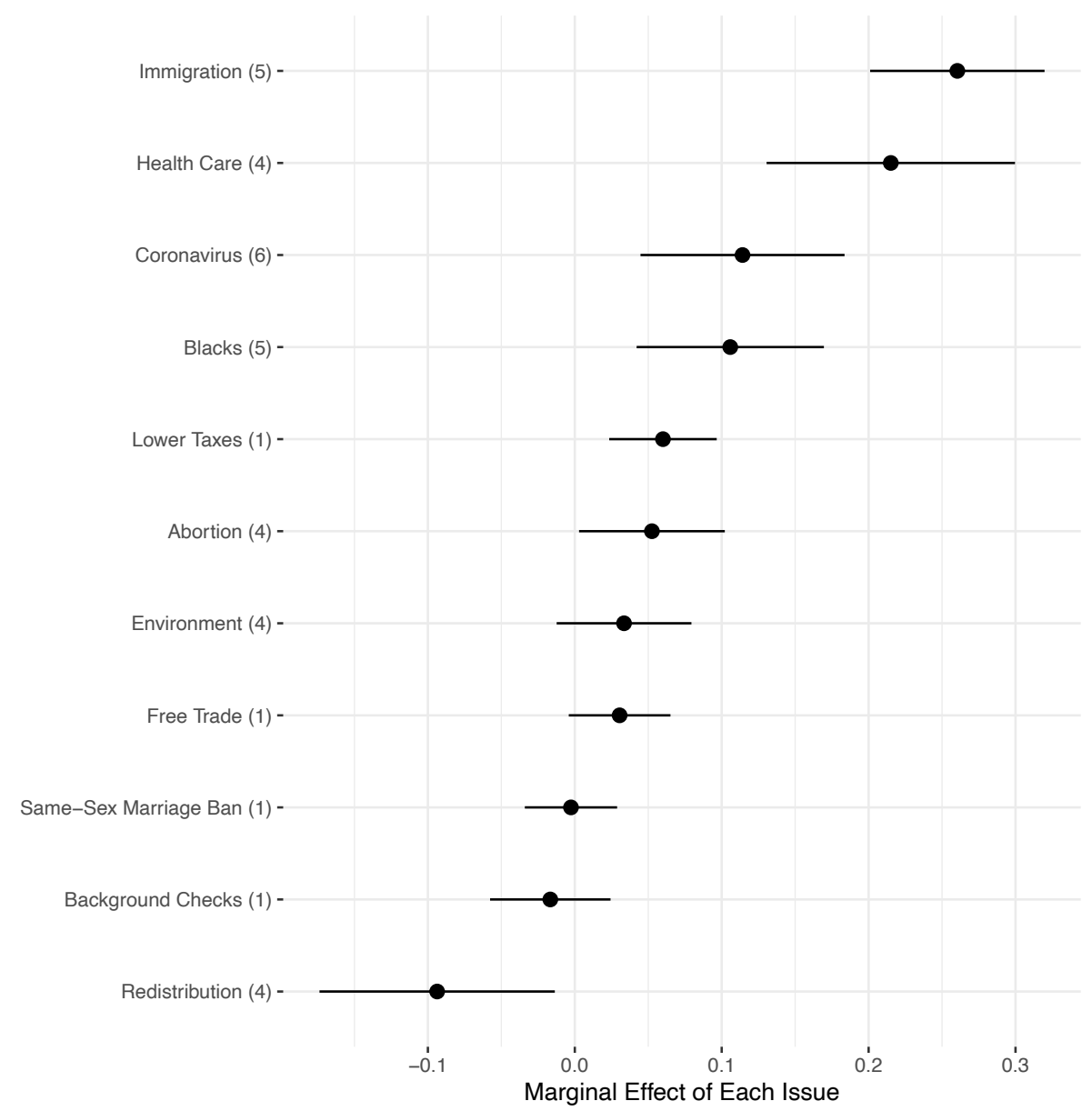

Note: This figure shows the marginal effect of attitude scales in each issue area on binary Trump (vs Biden) vote choice from a single linear probability model. The model controls for the conventional 7-point party identification scale and demographics.

Are coronavirus attitudes more strongly associated with vote choice among voters for whom the coronavirus is personally important, that is, among those who caught the virus or who have a close friend or family member who tested positive or died from the virus. Figure 7 shows the marginal effect (coefficient from linear probability models) of coronavirus attitudes on the probability of supporting Trump by issue importance. It is clear that coronavirus attitudes are associated with vote choice among respondents who do not have a close friend or family member who tested positive or who died. However, the relationship is near zero 
but imprecisely estimated among respondents with a close friend or family member who caught the virus or died. While there is considerable uncertainty among voters who were personally affected, there is no evidence that issue importance increases the relationship between coronavirus preferences and vote choice.

People with a close friend or family member who caught the virus or died may be different from people who did not experience these. To ensure that we are estimating these voting models in comparable groups, we created a matched data set for each of the two personal importance measures. Given the large size of our survey, we were able to achieve balance on the demographic variables we used for weighting. When we re-estimate the same voting models in these two match datasets, however, the results remain similar. If anything, these measures appear to be associated with less voting on coronavirus policies. 
Figure 7: Marginal Effect of Coronavirus Attitudes on Intention to Vote for Trump by Whether the Issue is Personally Important to a Voter

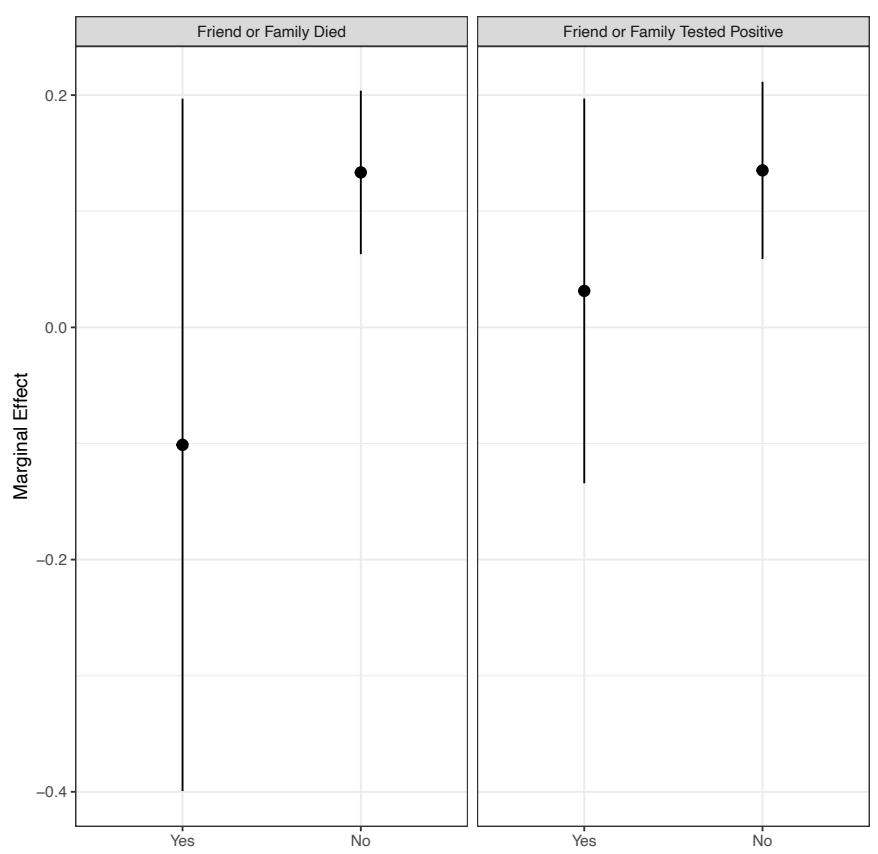

Note: This figure shows the marginal effect of the coronavirus scale on binary Trump (vs Biden) vote choice. It compares the marginal effect among voters who tested positive for the virus or who have a close friend or family member who tested positive to voters who were not personally affected in these ways. It also compares the marginal effect among voters with a close friend or family member who died from the virus to voters who do not have a close friend or family member who has died.

Would voters hold Trump accountable if they learned his and Biden's stances? This is a difficult question that we can't answer with certainty. To shed some light on it, Figure 8 presents Trump vote choice on the y-axis and the six-item coronavirus attitude scale on the $\mathrm{x}$-axis. In this figure, the scale is coded so that higher values represent more support for policies to fight the virus. It distinguishes voters with high knowledge (i.e. above median, meaning more than one of the three placements right) of the candidates' coronavirus positions from those with low knowledge (i.e. below median, meaning none or one placement right). It shows a strong relationship between coronavirus attitudes and vote choice among voters with high virus stance knowledge. The probability of voting for Trump falls from about 1 all the way down to 0 as high-knowledge voters become more supportive of measures to fight the 
virus. Among voters with low knowledge, however, that relationship is much weaker. Among them, the probability of intending to vote for Trump varies from just over 0.9 to about 0.6 as voters become more supportive of policies to fight the virus. More strikingly, even low knowledge voters who most strongly support policies to fight the virus have a high probability of supporting Trump (just above 0.60). Conversely, regardless of political knowledge, voters who are least supportive of policies to fight the virus very strongly support Trump. Thus, Trump seems to stay relatively popular by getting votes from voters who oppose policies to fight the virus regardless of their knowledge of candidates' stances and from voters who support such policies but do not realize that Trump is less supportive of them. 
Figure 8: Coronavirus Attitudes and Vote Choice by Knowledge of Candidate Stances

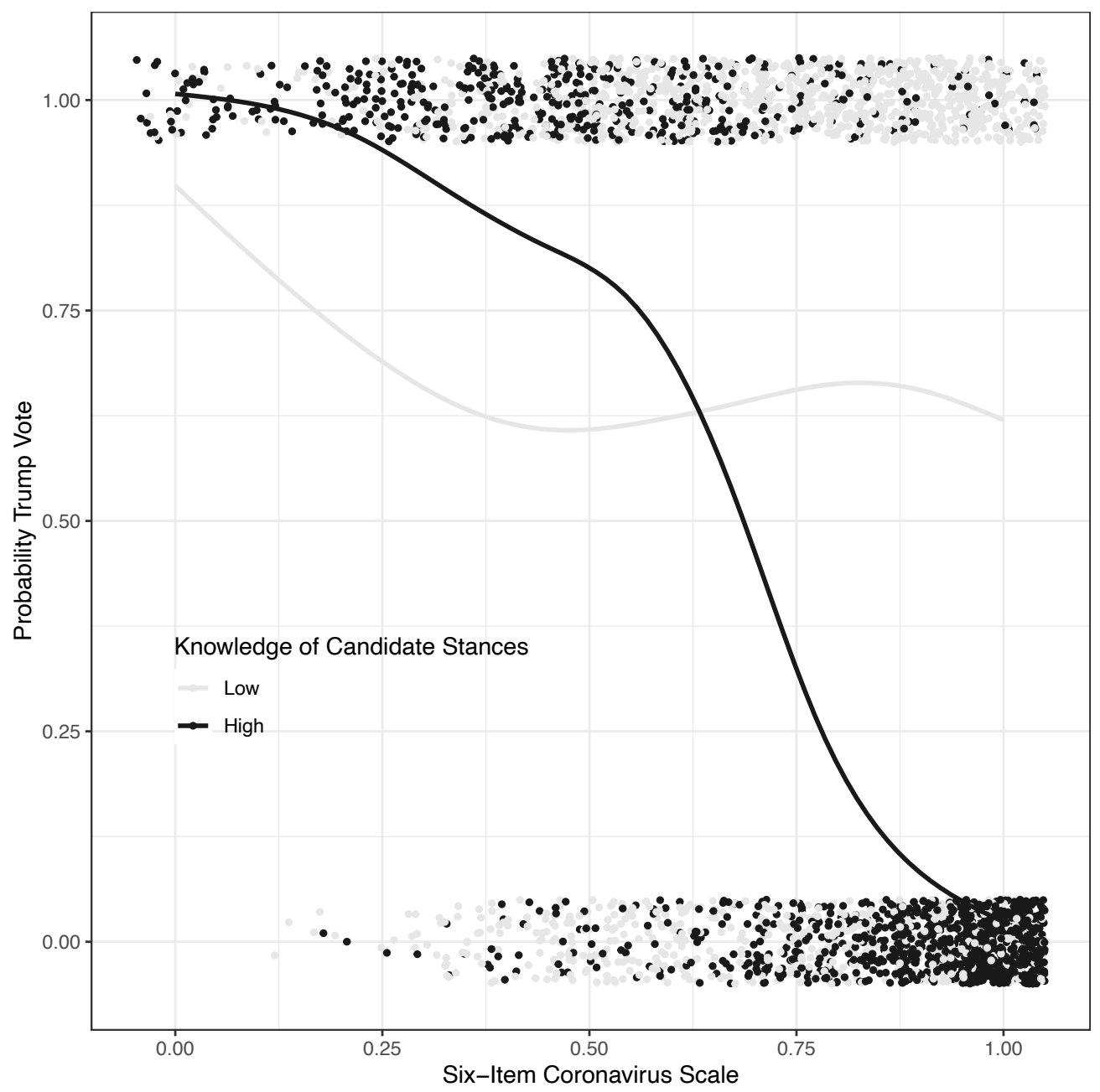

Note: This figure shows the relationship between the coronavirus attitudes scale and voting for Trump among voters with high (above median) and low (at or below median) knowledge of the candidates' coronavirus positions. Points are jittered and the coronavirus scale is coded so that higher values indicate stronger support for policies to fight the virus. It shows that the relationship between coronavirus attitudes and vote choice is much stronger among high knowledge voters. Moreover, among low-knowledge voters, the probability of supporting Trump is over 0.6 even among voters who support the strongest measures to fight the virus.

Lack of knowledge of candidate positions seems to be helping Trump. We simulated Trump's vote share assuming voters with low knowledge (below median) of the candidates' positions gave the same weight to issues as high-knowledge voters (above median). We found that Trump's vote share would drop from 48 percent to 43 percent. This simulation, 
of course, makes a host of assumptions, but nevertheless suggests that Trump would lose support if voters knew more about the candidates' positions on the coronavirus.

\section{Conclusion}

Given the infinitesimally small chance voters will ever cast a decisive vote, voters lack an incentive to pay attention to politics and thus to vote in a way that reflects their policy preferences. As a result, voters know surprisingly little about presidential candidates' policy stances. However, there is a long-running argument that, even though voters may not be able to vote in a way that is consistent with their policy attitudes on most issues, on some issues that are particularly salient or important to them, voters should be able to develop vote preferences that are consistent with their policy preferences (Converse 1964; Krosnick 1990b). We tested this possibility on an issue that is undeniably important to voters: the coronavirus crisis.

Despite facing the greatest crisis in the US since World War II, voter knowledge about Trump's and Biden's stances on coronavirus policies are seemingly low. They are typical of the generally low levels found across most policy issues. In the absence of knowledge, voters appear to project their positions onto their preferred candidate. Motivated reasoning and cheerleading may also contribute to low levels of knowledge. Even among respondents who lack incentives to engage in motivated reasoning, however, we still find surprisingly low levels of knowledge.

Why have many voters failed to learn Trump's and Biden's stances. One explanation is that, even though people's lives are disrupted, they still face the core collective action problem at the heart of democracy - they lack an incentive to learn about politics since their votes will never matter. Another possibility is that they desire to learn but the pandemic has

left them with even less time and other resources to engage (Verba, Schlozman and Brady 1995). Another possibility is that interest in politics may be too stable over the lifetime, 
reflecting a long-standing predisposition (Prior 2018), one not responsive to severe crises.

These findings have implications for the 2020 Presidential election. The coronavirus crisis is likely to have a smaller effect than its importance would indicate. More fundamentally, our findings have implications for our understanding of voting behavior. Issue importance does not seem to help voters connect their policy preferences to their vote choice. Instead, voters seem to project their positions onto their preferred candidate. Only on issues on which parties have acquired strong reputations over the past few years do majorities of voters have knowledge of the candidates' positions. Consequently, a candidate may be able to win an election despite holding unpopular stances on an important issue. 


\section{References}

Alaminos, Antonio and Clemente Penalva. 2012. "The Cognitive Mobilization Index: Crises and Political Generations." SAGE Open 2(1):2158244012440437.

Ansolabehere, Stephen, Jonathan Rodden and James M Snyder. 2008. "The Strength of Issues: Using Multiple Measures to Gauge Preference Stability, Ideological Constraint, and Issue Voting." American Political Science Review 102(2):215-232.

Aronow, Peter Michael, Joshua Kalla, Lilla Orr and John Ternovski. 2020. "Evidence of Rising Rates of Inattentiveness on Lucid in 2020.".

URL: 10.31235/osf.io/8sbe4

Bartels, Larry M. 2000. "Partisanship and Voting Behavior, 1952-1996." American Journal of Political Science 44:35-50.

Bartle, John and Samantha Laycock. 2012. "Telling more than they can know? Does the most important issue really reveal what is most important to voters?" Electoral Studies 31(4):679-688.

Bolsen, Toby and Thomas J Leeper. 2013. "Self-Interest and Attention to News Among Issue Publics." Political Communication 30(3):329-348.

Boninger, David S, Jon A Krosnick, Matthew K Berent and Leandre R Fabrigar. 1995. The Causes and Consequences of Attitude Importance. In Attitude strength: Antecedents and consequences, ed. Richard E Petty and Jon A Krosnick. pp. 159-189.

Brody, Richard A and Benjamin I Page. 1972. "Comment: The Assessment of Policy Voting." American Political Science Review 66(2):450-458.

Bullock, John G, Alan S Gerber, Seth J Hill and Gregory A Huber. 2015. "Partisan Bias in Factual Beliefs about Politics." Quarterly Journal of Political Science 10(4):519-578. 
Campbell, Angus, Philip Converse, Warren Miller and Donald Stokes. 1960. The American Voter. New York: Wiley.

Conover, Pamela Johnston and Stanley Feldman. 1982. "Projection and the perception of candidates' issue positions." Western Political Quarterly 35(2):228-244.

Converse, Philip E. 1964. The Nature of Belief Systems in Mass Publics. In Ideology and Discontent, ed. David E Apter. London: Free Press of Glencoe pp. 206-261.

Coppock, Alexander and Oliver A McClellan. 2019. "Validating the Demographic, Political, Psychological, and Experimental Results Obtained from a New Source of Online Survey Respondents." Research \& Politics 6(1):2053168018822174.

Dahl, Robert A. 1966. Who governs? Democracy and Power in an American City. New Haven: Yale University Press.

Downs, Anthony. 1957. An Economic Theory of Democracy. New York: Harper.

Festinger, Leon. 1957. A Theory of Cognitive Dissonance. Stanford: Stanford University Press.

Freeder, Sean, Gabriel S Lenz and Shad Turney. 2019. "The Importance of Knowing "What Goes with What": Reinterpreting the Evidence on Policy Attitude Stability." The Journal of Politics 81(1):274-290.

Gartner, Scott Sigmund. 2008. "Ties to the dead: Connections to Iraq War and 9/11 casualties and disapproval of the president." American Sociological Review 73(4):690-695.

Gelman, Andrew. 2013. "The Average American Knows How Many People?" The New York Times .

Grynaviski, Jeffrey D. and Bryce E. Corrigan. 2006. "Specification Issues in Proximity Models of Candidate Evaluation (with Issue Importance)." Political Analysis 14(4):393420. 
Hanretty, Chris, Benjamin E Lauderdale and Nick Vivyan. 2020. "A Choice-Based Measure of Issue Importance in the Electorate." American journal of political science .

Heider, Fritz. 1958. The Psychology of Interpersonal Relations. New York: Wiley.

Johns, Robert. 2010. "Measuring issue salience in British elections: competing interpretations of "most important issue"." Political Research Quarterly 63(1):143-158.

Kern, Anna, Sofie Marien and Marc Hooghe. 2015. "Economic Crisis and Levels of Political Participation in Europe (2002-2010): The Role of Resources and Grievances." West European Politics 38(3):465-490.

Krosnick, Jon A. 1988. "The Role of Attitude Importance in Social Evaluation: A Study of Policy Preferences, Presidential Candidate Evaluations, and Voting Behavior." Journal of personality and social psychology 55(2):196.

Krosnick, Jon A. 1990a. "Americans' perceptions of presidential candidates: A test of the projection hypothesis." Journal of Social Issues 46(2):159-182.

Krosnick, Jon A. 1990b. "Government Policy and Citizen Passion: A Study of Issue Publics in Contemporary America." Political Behavior 12(1):59-92.

Kunda, Ziva. 1990. "The Case for Motivated Reasoning." Psychological Bulletin 108:480-498.

Layman, Geoffrey C. and Thomas M. Carsey. 2002. "Party Polarization and 'conflict Extension' in the American Electorate." American Journal of Political Science 46:786-802.

Lecheler, Sophie, Claes de Vreese and Rune Slothuus. 2009. "Issue Importance as a Moderator of Framing Effects." Communication Research 36(3):400-425.

Leeper, Thomas J and Joshua Robison. 2020. "More important, but for what exactly? The insignificant role of subjective issue importance in vote decisions." Political Behavior 42(1):239-259. 
Lenz, Gabriel. 2012. Follow the Leader? How Voters Respond to Politicians' Policies and Performance. Chicago; London: The University of Chicago Press.

Martinez, Michael D. 1988. "Political Involvement and the Projection Process." Political Behavior 10(2):151-167.

Miller, Joanne M, Jon A Krosnick and Leandre R Fabrigar. 2017. "The Origins of Policy Issue Salience." Political psychology: New Explorations pp. 125-172.

Mullinix, Kevin J. 2016. "Partisanship and Preference Formation: Competing Motivations, Elite Polarization, and Issue Importance." Political Behavior 38(2):383-411.

Prior, Markus. 2018. Hooked: How Politics Captures People's Interest. New York: Cambridge University Press.

Tomz, Michael and Robert P Van Houweling. 2009. "The Electoral Implications of Candidate Ambiguity." American Political Science Review pp. 83-98.

Verba, Sidney, Kay Lehman Schlozman and Henry E. Brady. 1995. Voice and Equality: Civic Voluntarism in American Politics. Cambridge, Mass.: Harvard University Press.

Zaller, John. 1992. The Nature and Origins of Mass Opinion. Cambridge: Cambridge University Press. 


\section{Appendix}

Figure A.1: Placement Knowledge Among Biden Voters

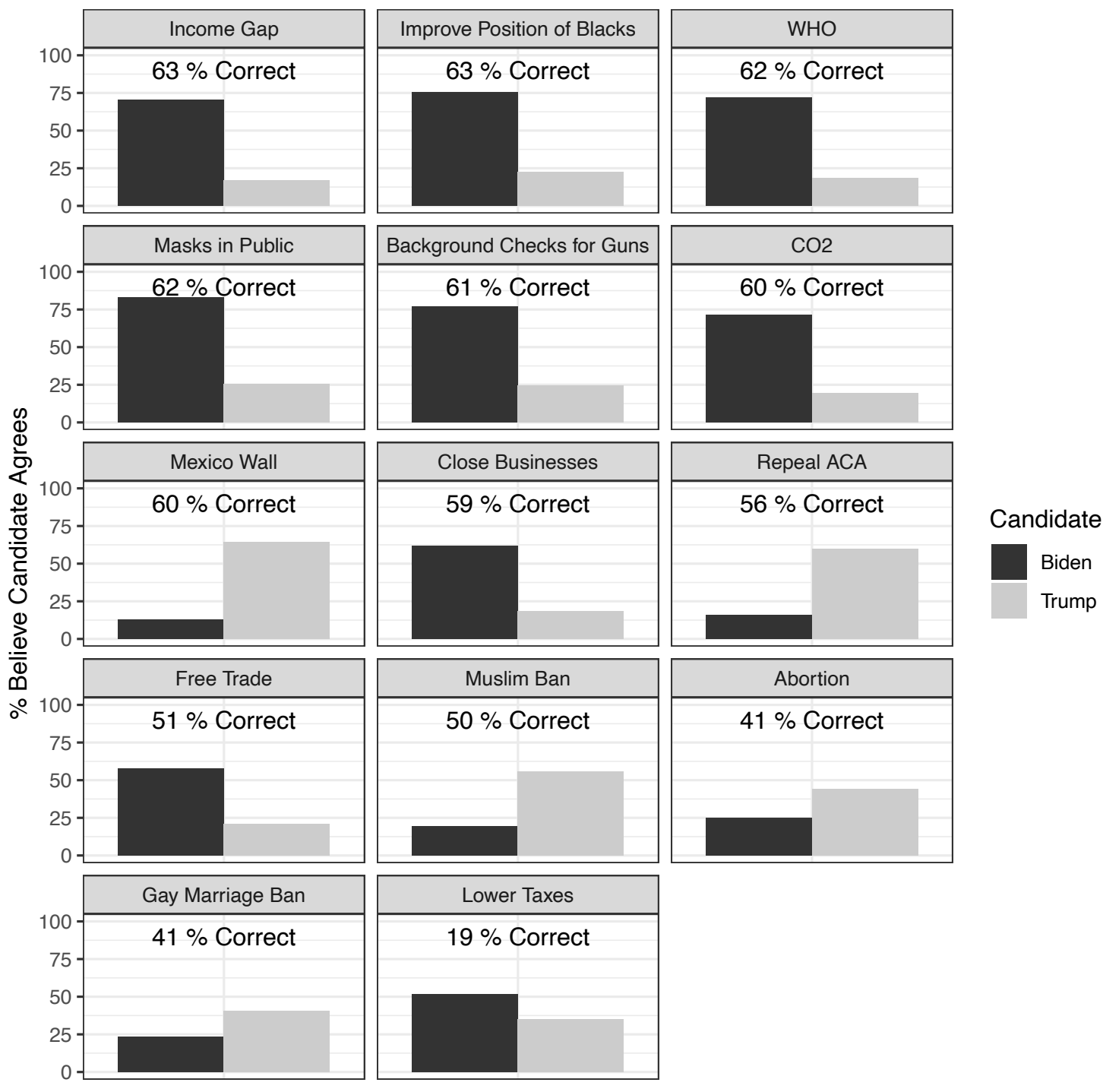

Note: Bars in this figure show the percentage of Biden voters who believe each candidate agrees with each policy statement. At the top of each facet, the percentage of respondents who correctly place the candidates relative to each other on the issue is indicated. Issues are ordered by the percentage of Biden voters who correctly place the candidates. 
Figure A.2: Placement Knowledge Among Trump Voters

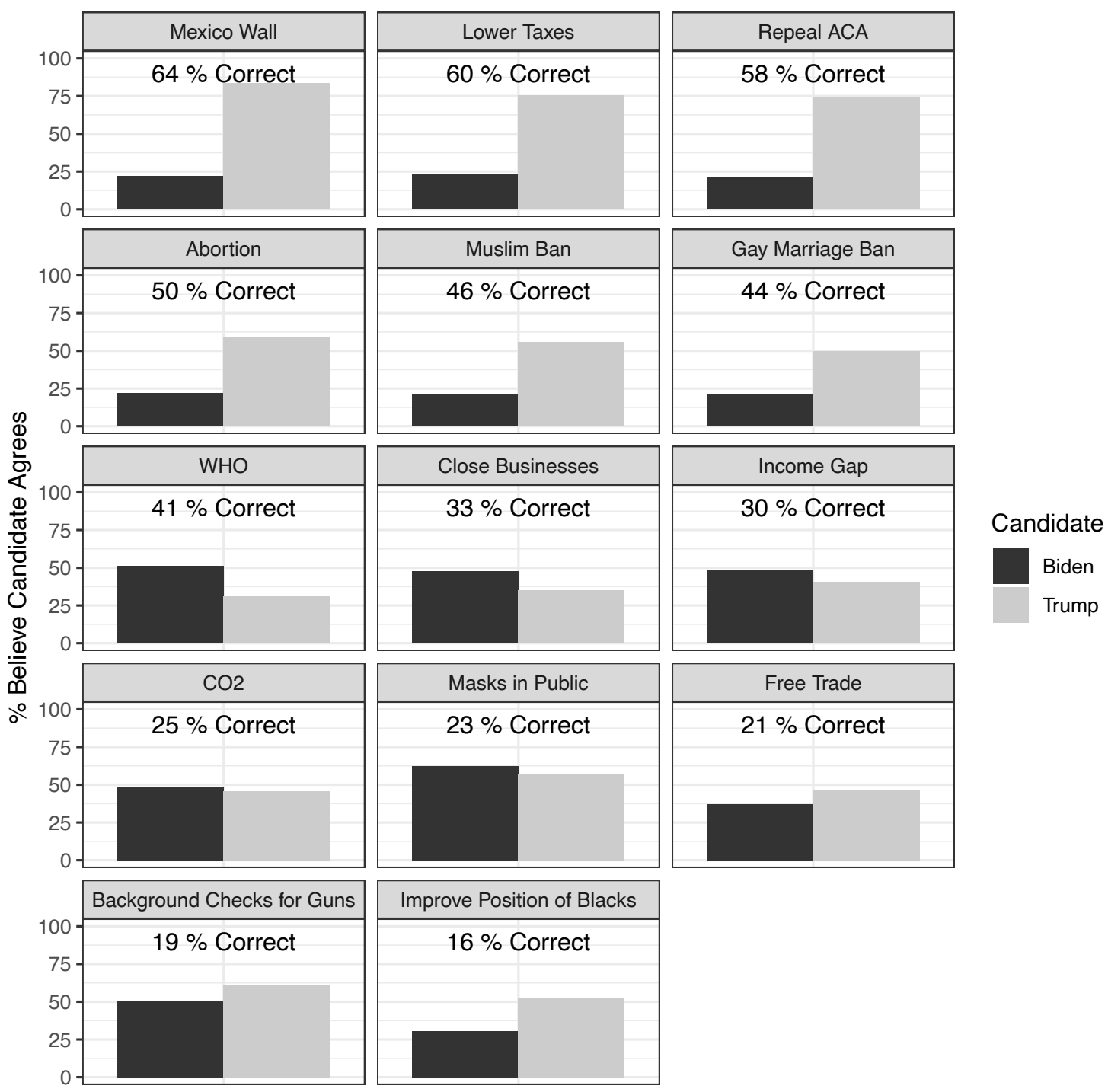

Note: Bars in this figure show the percentage of Trump voters who believe each candidate agrees with each policy statement. At the top of each facet, the percentage of respondents who correctly place the candidates relative to each other on the issue is indicated. Issues are ordered by the percentage of Trump voters who correctly place the candidates. 
Figure A.3: Presidential Candidate and Party Policy Stance Knowledge in the ANES $1972-2016$

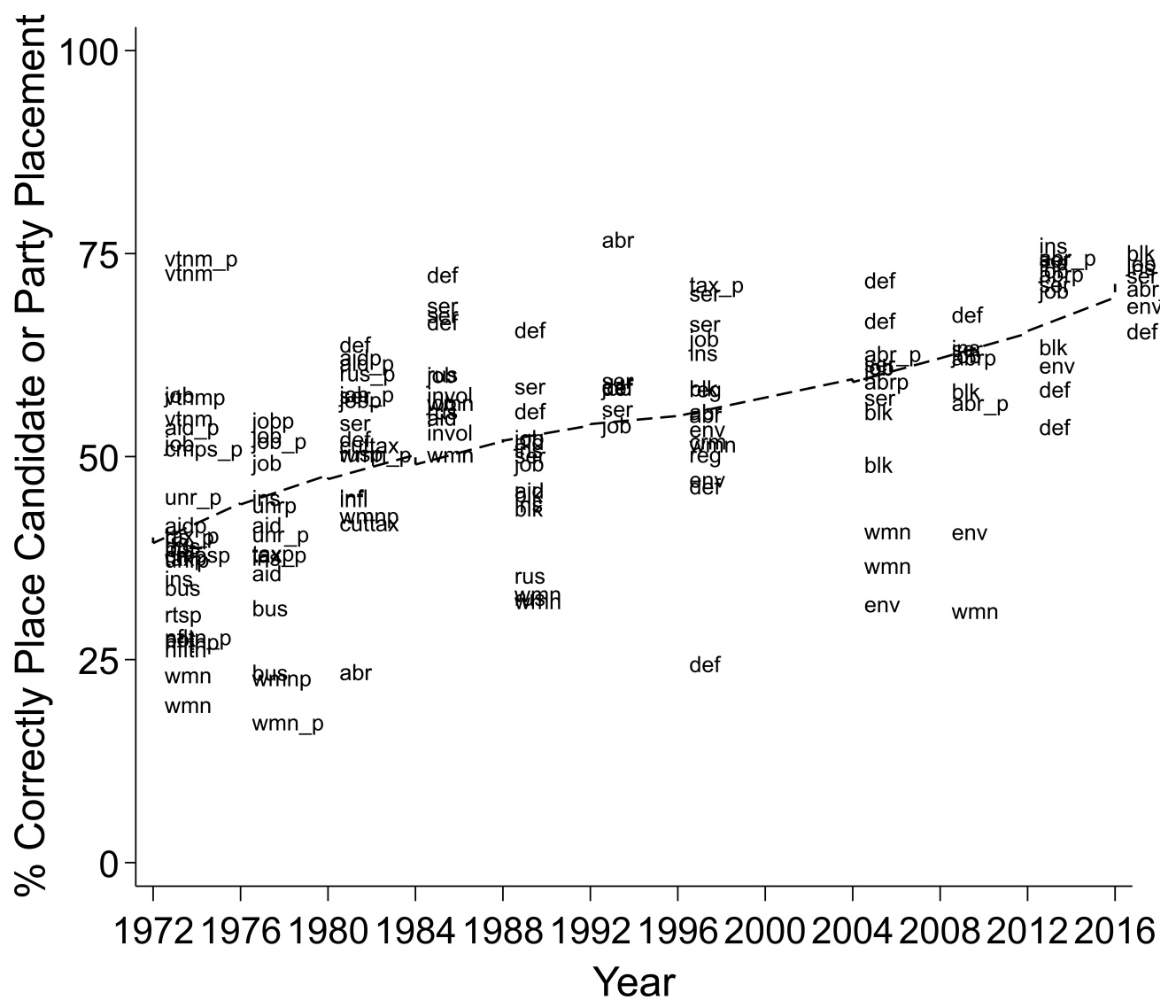

Note: This figure presents the percent placing the candidates and the percent placing the parties on the right sides of each other for all available policy questions across ANES presidential election surveys. As in the paper, we code respondents as "correct" if they place the Democratic presidential candidate to the ideological left of the Republican anywhere on the scale for the presidential candidate questions. Likewise we code respondents as correct if they place the Democratic party to the ideological left of the Republican Party for the party placement questions. We code respondents who placed the candidates or parties at the same point, say don't know to one or both candidates/parties or reverse the positions as incorrect. In 2016, the ANES only asked about party positions. Before 1972, the ANES did not ask about policy stance perceptions of presidential candidates or parties. We do not show the percentages for 2000 because of the split phone/face-to-face design. We weight the estimates in years when the ANES calculates weights.

Issue legend: tax (High-income tax-rate), unr (Urban unrest), cmps (College campus unrest), job (Government guaranteed jobs), pot (Legalization of marijuana), bus (School bussing), ins (Government provided health insurance), wmn (Women's role in society), rts (Rights of the accused), aid ("Aid to minorities"), blk (Aid to blacks), def (Defense spend- 
ing), ser (Government services and spending), infl (Inflation-unemployment tradeoff), abr (Abortion), invol (US involvement in Central America), rus (Cooperation with Russia), crm (Crime reduction), env (Environment-Jobs tradeoff), reg (Environmental Regulation). "_p" indicates that a question is from the postelection survey wave.

Several factors may account for the lower percent correct we observe in the Lucid survey compared to 2016 ANES. In 2016, the ANES only asked about party placements, whereas our survey asked about presidential placements. Other factors may include that our survey took place in August, whereas ANES usually interviews respondents across September and October and then after the election, giving people more time to learn from campaign exposure. The ANES may select for more politically knowledgeable respondents who are willing to sit through an hour-long survey about politics, whereas Lucid respondents mostly answer short marketing surveys. Low-quality responding from Lucid respondents may also contribute, as we discuss in the paper. Question format differences may also contribute.

In 2012, the ANES had a unusually low response rate, which may account for the somewhat higher numbers in that year. In 2016, however, the response rate rose. 